\title{
FEED VALUE OF BLUE PANIC (Panicum antidotale retz.) GRASS AT DIFFERENT GROWTH STAGES AND UNDER VARYING LEVELS OF HUMIC ACID IN SALINE CONDITIONS
}

\author{
Ihsanullah DAUR \\ King Abdulaziz University, Faculty of Meteorology, Environment \& Arid Land Agriculture, Department \\ of Arid Land Agriculture, Jeddah, SAUDI ARABIA \\ Corresponding author: iaslam@kau.edu.sa
}

Received: 09.06.2016

\begin{abstract}
This study underscored an underexploited crop, blue panic grass as a potential crop for hot and saline regions. It investigated feed value of the crop at two growth stages, before flowering (BF) and after flowering (AF), and under different levels of humic acid application (HA, at $0,15,30,45,60,75$, and $\left.90 \mathrm{~kg} \mathrm{ha}^{-1}\right)$. Significant $(\mathrm{P}<$ 0.05) effects of different growth stages, HA while non-significant effect of their interactions were observed for various parameters. Low dry matter (DM) was recorded for cutting at BF than that for AF, whereas the DM production increased with increasing HA levels. For plants at BF stage, low acid detergent fiber (ADF) and low neutral detergent fiber (NDF) levels were observed. In contrast, leaf/stem ratio, digestible dry matter (DDM), crude protein $(\mathrm{CP})$ content, and the concentrations of macro and micro elements, were all high in plants at BF stage. A similar pattern for all the above mentioned parameters was observed for augmentation of HA. The study suggests the application of $75-90 \mathrm{~kg} \mathrm{ha}^{-1} \mathrm{HA}$ to the soil, whereas cutting of the crop at BF stage for enhancing both the yield and quality of the crop. Furthermore, findings of this study are expected to be a valuable reference for researchers and producers, because it broadly highlights the grass feed values.
\end{abstract}

Key words: Crude protein, DDM, dry matter, forage, mineral composition, NDF

\section{INTRODUCTION}

Blue panic (Panicum antidotale Retz.) is an important perennial grass that has an immense potential for growing in stress condition (Jung et al., 1990; Zhang et al., 2012; Descheemaeker et al., 2014). However, due to the limited agronomic information about its potential for growing in saline condition, and forage value, it has not received much attention as a fodder crop, and is therefore, not grown widely across the world for forage purposes. Thus up until now, its' growth stage for cutting has not been established. This study explored the feed value of this grass, under saline conditions because it is supposed a good choice for growing under salt stress. Moreover, humic acid is widely believed to enhance crop growth under saline conditions - so we wanted to explore its addon advantage in salt tolerance.

Previously, blue panic species have been investigated botanically or physiologically, for example for their water use efficiency (Shahbaz et al. 2011), for their morphology and anatomy (Hameed et al. 2012; Nawaz et al. 2013), and for their heat tolerance (Wasim et al. 2013). However, data regarding blue panic growth, yield, and feed value have been lacking so far. Crop growth and feed values are important considerations for adopting specific crop species as livestock forage (Long et al. 1999; Barry 2013, Geren and Kavut, 2015). Dong et al. (2013) and Geren (2014) underscored that for determining the feed value of a crop, plant height, leaf/stem ratio, dry matter content, crude protein (CP), acid detergent fiber (ADF), and neutral detergent fiber (NDF) are important parameters. In addition, Atis et al. (2015) reported that forage yield, composition, and quality are directly related to its harvesting time. Likewise, a humic acid have been reported to enhance nutrient availability, nutrient absorption, nutrient utilization, plant growth, physiology and metabolism through various mechanisms and is therefore believed to enhance crop yield under saline condition (Schiavon et al., 2010; Berbara \& Garcia, 2014).

Based on previous research and the literature, this study focused on several parameters related to the growth, nutritional value, and the mineral composition of blue panic grass at the two different growth stages, under natural saline conditions. The natural saline conditions in this study represent predominant saline conditions around the world, so it is expected that the results to be relevant globally. 


\section{MATERIALS AND METHODS}

\section{Experimental details}

A 2-years field experiment on growing blue panic was conducted at Hada A'Sham area of Jeddah, Saudi Arabia during 2011 \& 2012. The average monthly temperature and precipitation for the site are presented in Table 1. Furthermore, the site initial soil properties and after completion of the experiment, for selected treatments is presented in Table 2. Blue panic seeds from Pacific Seed Company were used in the experiment. Each year the seeds were sown in the first week of January using rowto-row distance of $30 \mathrm{~cm}$. A new section of the experimental field was used each year. The humic acid (HA) levels $\left(0,15,30,45,60,75\right.$, and $\left.90 \mathrm{~kg} \mathrm{ha}^{-1}\right)$ were applied to the soil in powder form, two weeks prior to sowing of the crop by incorporation in upper $15 \mathrm{~cm}$ soil layer, whereas the crop harvesting was managed at two growth stages, according to the experimental treatment. The experiment was conducted in a randomized complete block design with a split-plot arrangement (growth stages as the main plot factor and HA as a sub-plot factor). Each sub-plot size was $2 \times 2.5 \mathrm{~m}^{2}$. Plots allotted to BF (before flowering) stage were harvested just before flowering initiation, whereas plots allotted to AF (after flowering) stage were harvested after complete flowering. Saline borehole water of $4000 \mathrm{ppm}$ was used for irrigating the crops. Just one time weeding was practiced - that was done manually 20 days after sowing. All other agronomic practices were carried out uniformly across all treatments.

Table 1. Mean monthly temperature $\left({ }^{\circ} \mathrm{C}\right)$ and precipitation at experimental sites.

\begin{tabular}{|c|c|c|c|c|c|c|c|c|c|c|c|c|}
\hline \multirow{2}{*}{ Weather Parameters } & \multicolumn{12}{|c|}{ Months } \\
\hline & Jan & Feb & Mar & Apr & May & Jun & Jul & Aug & Sep & Oct & Nov & Dec \\
\hline Min. $\mathrm{T}^{\circ} \mathrm{C}(2011)$ & 14.5 & 16.7 & 18.6 & 21.5 & 22.9 & 24.8 & 26.1 & 27.4 & 25.2 & 23.1 & 22.8 & 18.5 \\
\hline Min. $\mathrm{T}^{\circ} \mathrm{C}(2012)$ & 15.5 & 18.1 & 18.4 & 21.4 & 23.5 & 25.0 & 26.3 & 27.5 & 25.4 & 22.9 & 23.0 & 19.0 \\
\hline Long term min. $\mathrm{T}^{\circ} \mathrm{C}$ & 15.6 & 18.1 & 19.2 & 21.0 & 23.2 & 24.0 & 26.1 & 27.0 & 25.2 & 23.5 & 22.1 & 19.0 \\
\hline Max. $\mathrm{T}^{\circ} \mathrm{C}(2011)$ & 28.0 & 29.1 & 29.5 & 33.0 & 35.1 & 36.4 & 37.0 & 37.5 & 35.8 & 35.0 & 30.1 & 28.1 \\
\hline Max. $\mathrm{T}^{\circ} \mathrm{C}(2012)$ & 28.3 & 29.2 & 28.4 & 32.6 & 34.8 & 36.0 & 36.9 & 37.2 & 36.0 & 35.2 & 30.0 & 28.2 \\
\hline Long term max. $\mathrm{T}^{\circ} \mathrm{C}$ & 28.1 & 29.0 & 30.4 & 32.8 & 35.0 & 36.0 & 37.1 & 37.5 & 36.2 & 35.0 & 39.8 & 28.1 \\
\hline 2011 Rainfall (mm) & 4.9 & - & - & - & - & - & - & - & - & - & 25.0 & 30.4 \\
\hline 2012 Rainfall (mm) & 4.4 & 3.08 & - & - & - & - & - & - & - & 1.12 & 12.2 & 10.0 \\
\hline $\begin{array}{l}\text { Long term Rainfall } \\
(\mathrm{mm})\end{array}$ & 4.5 & 1.18 & 1.2 & 0.5 & - & - & & - & - & 0.89 & 3.2 & 3.3 \\
\hline
\end{tabular}

Table 2. Soil properties of the site $(0-30 \mathrm{~cm})$ initially and after completion of the experiment

\begin{tabular}{|c|c|c|c|c|}
\hline \multirow{2}{*}{ Soil properties } & \multirow{2}{*}{ Initial values } & \multicolumn{3}{|c|}{ After completion of the experiment for selected treatments } \\
\hline & & 0 HA ha-1 & 75 HA ha $^{-1}$ & $90 \mathrm{HA} \mathrm{ha}^{-1}$ \\
\hline $\mathrm{pH}$ & 7.80 & 7.79 & 7.74 & 7.72 \\
\hline Organic matter $(\%)$ & 1.86 & 0.81 & 1.21 & 1.22 \\
\hline $\mathrm{CEC}\left(\mathrm{cmol}_{\mathrm{c}} \mathrm{kg}^{-1}\right)$ & 13.21 & 13.21 & 16.11 & 16.11 \\
\hline $\mathrm{EC}(d S / m)$ & 1.74 & 1.78 & 1.76 & 1.76 \\
\hline Soil texture & Loamy Sand & Loamy Sand & Loamy Sand & Loamy Sand \\
\hline Total N $(\%)$ & 0.11 & 0.10 & 0.12 & 0.12 \\
\hline \multicolumn{5}{|c|}{ Quantity $\left(\mathrm{mg} \mathrm{kg}^{-1}\right)$} \\
\hline $\mathrm{P}$ & 48.7 & 49.2 & 46.0 & 46.4 \\
\hline $\mathrm{K}$ & 304.1 & 288.5 & 344.3 & 352.6 \\
\hline $\mathrm{Ca}$ & 4166 & 3452 & 4134 & 4222 \\
\hline $\mathrm{Mg}$ & 234 & 122 & 247 & 252 \\
\hline $\mathrm{S}$ & 154 & 122 & 118 & 116 \\
\hline $\mathrm{Na}$ & 324 & 346 & 340 & 344 \\
\hline $\mathrm{B}$ & 10.4 & 9.7 & 9.8 & 9.8 \\
\hline Mn & 14.0 & 12.1 & 13.8 & 13.9 \\
\hline $\mathrm{Fe}$ & 48.12 & 34.10 & 60.2 & 64.0 \\
\hline Co & 4.5 & 4.3 & 4.4 & 4.4 \\
\hline $\mathrm{Cu}$ & 1.61 & 1.20 & 1.48 & 1.55 \\
\hline $\mathrm{Zn}$ & 2.86 & 1.11 & 3.12 & 3.11 \\
\hline
\end{tabular}

\section{Soil physical and chemical analysis}

To determine soil properties, random soil samples were taken from the experimental field at a depth of 0-30 $\mathrm{cm}$ and were mixed as a composite sample to determine the initial soil properties. After completion of the experiment, similarly soil samples were collected from the control, as well as from the sub-plots with selected treatments of HA, for comparative analysis of various soil properties. Soil $\mathrm{pH}$, texture, and electrical conductivity (EC) were determined following standard procedures 
(Daur, 2014). The cation exchange capacity (CEC) was measured following the method of Page et al. (1982), and organic matter was determined using the Walkley-Black method (Nelson and Sommers, 1996). Nitrogen (N) content was quantified using a Perkin-Elmer CHNS/O Analyzer (Model 2400), following the manufacturer's instructions (PerkinElmer, Inc., USA). Phosphorus (P) was determined colorimetrically, following the protocol described by Ryan et al. (2001), whereas all other elements (K, Ca, Mg, S, Na, B, Mn, Fe, Co, Cu and Zn) were determined using Varian inductively coupled plasma-optical emission spectroscopy (ICP-OES) according to manufacturer's instructions.

\section{Crop yield and feed value}

To assess crop yield and the apparent quality, data on plant height, crop dry matter (DM), and leaf/stem ratio were compiled each year on the basis of 3 cuts. Each cut took on the average 35 days to $\mathrm{BF}$ stage and 45 days $\mathrm{AF}$ stage. During each cut the data was recorded following proper agronomic procedures as described earlier (Daur et al., 2011; Daur and Tatar, 2013). Dry matter yield was determined by oven-drying the samples at $65^{\circ} \mathrm{C}$ for 48 hours, following procedure of Daur and Tatar (2013) with some modifications. Instead of drying the whole plants, they were separated into leaf and stem fractions to determine their respective dry matter and total DM per cut.

The crop feed value was evaluated based on the chemical composition, by analyzing the crop's dry matter samples from each sub-plot at all cuts - and then means per cut were workout. For the analysis of each cut, the oven dried plant samples were milled to $1 \mathrm{~mm}$, and these samples were analyzed for crude protein (CP), neutral detergent fiber (NDF), and acid detergent fiber (ADF) contents, as well as digestible dry matter (DDM), and mineral composition. Crude protein content was determined using the equation of $\mathrm{N} \times 6.25$, as described in AOAC method 2001.11 (AOAC, 2000). NDF and ADF for all samples were determined following the procedure of Van Soest et al. (1991), whereas DDM was calculated using the following equation (Mertens, 1987): DDM = $88.9-0.78 \times \mathrm{ADF}$

The nitrogen content $(\mathrm{N})$ was determined using a Perkin-Elmer CHNS/O Analyzer (Model 2400), following the manufacturer's instructions (PerkinElmer, Inc., USA). Phosphorus was determined colorimetrically, following the protocol described by Ryan et al. (2001). All the other elements (K, Ca, Mg, S, Na, B, Mn, Fe, Co, Cu and Zn) were determined by ICP-OES according to manufacturer's instruction manual.

\section{Statistical analysis}

Statistical analyses of the data, and the calculation of the least significant differences (LSD) $(\mathrm{P}<0.05)$ were conducted using SAS software.

\section{RESULTS}

Growth stage (GS) and humic acid (HA) levels significantly $(\mathrm{P}<0.05)$ influenced plant height, DM, leaf/stem ratio, $\mathrm{CP}, \mathrm{NDF}, \mathrm{ADF}$, and DDM, whereas their interaction (GS $\times$ HA) did not (Table 3). Statistically significant highest plant height $(55.80 \mathrm{~cm})$ and DM $(7.80$ tons $\mathrm{ha}^{-1}$ ) were observed for $90 \mathrm{~kg} \mathrm{ha}^{-1} \mathrm{HA}$ application level at AF stage. In contrast lowest plant height (42.11 $\mathrm{cm})$ and DM (6.16 tons $\left.\mathrm{ha}^{-1}\right)$ were for BF stage in control plots. However, highest leaf/stem ratio of DM (1.72) was recorded for $90 \mathrm{~kg} \mathrm{ha}^{-1} \mathrm{HA}$ level at $\mathrm{BF}$ stage. For HA treatments, the corresponding LSD values indicate that these quantities at $90 \mathrm{~kg} \mathrm{HA} \mathrm{ha}{ }^{-1}$ are statistically comparable to those observed at levels of $75 \mathrm{~kg} \mathrm{HA} \mathrm{ha}^{-1}$ or lower in their relevant growth stages. This indicates that HA application stimulates the crop growth at smaller HA doses, and that higher HA levels can increasingly boost the crop growth. Additionally, ranges with larger values for plant height $(48.40-55.80 \mathrm{~cm})$ and total DM production per cut (6.55-7.80 tons ha-1) were observed for AF stage compared to $\mathrm{BF}$ where plant height and $\mathrm{DM}$ production per cut ranged $(42.11-48.18 \mathrm{~cm})$ and $(6.16-$ 6.98 tons $\mathrm{ha}^{-1}$ ) respectively. However, leaf/stem ratio was with greater values (1.20-1.72) at BF stage compared to AF stage $(1.00-1.40)$. Also, the ranges for CP $(8.60$ 9.61\%), NDF (54.00-58.81\%), ADF (24.20-31.23\%), and DDM (64.54-7.02\%) were more desirable in terms of forage value at $\mathrm{BF}$ stage of the plant compared with $\mathrm{AF}$ stage. In the AF stage, the aforementioned ranges were as follows: $\mathrm{CP}$ (7.00-7.84\%), NDF (58.80-72.24\%), ADF (30.00-38.36\%), and DDM (58.98-65.50\%). In each of the relevant growth stages, there was no difference in results between adding 75 or $90 \mathrm{~kg} \mathrm{ha}^{-1}$ of HA applications $(\mathrm{P}<0.05)$, although compared with all the other HA applications levels, either one or both of these treatments were significantly more advantageous.

Likewise, analyses of macroelements indicated that $\mathrm{N}$, $\mathrm{P}, \mathrm{K}$, and $\mathrm{Mg}$ contents ( $\mathrm{g} \mathrm{kg}^{-1}$ of $\mathrm{DM}$ ) were significantly higher for plant in BF stage compared with $\mathrm{AF}(\mathrm{P}<0.05)$, and that there was no significant difference in $\mathrm{Ca}, \mathrm{S}$, and Na contents (Table 4). Likewise, N, P, K, and Mg contents increased significantly with increasing HA applications levels, although $\mathrm{Ca}, \mathrm{S}$, and $\mathrm{Na}$ were not influenced by $\mathrm{HA}$ levels. In addition, no significant interaction of GS and HA was found for any of the macroelements.

Analysis of microelements revealed that $\mathrm{B}, \mathrm{Mn}, \mathrm{Fe}$, $\mathrm{Cu}$, and $\mathrm{Zn}$ contents $\left(\mathrm{mg} \mathrm{kg}^{-1}\right.$ of $\left.\mathrm{DM}\right)$ were significantly $(\mathrm{P}<0.05)$ higher in plants at $\mathrm{BF}$ stage compared with $\mathrm{AF}$ (Table 5). In contrast, Co did not differ significantly between both growth stages. Across the levels of HA applications, $\mathrm{B}, \mathrm{Fe}, \mathrm{Cu}$, and $\mathrm{Zn}$ contents $\left(\mathrm{mg} \mathrm{kg}^{-1}\right.$ of $\left.\mathrm{DM}\right)$ significantly increased with higher HA levels while Mn and Co were non-significant. Finally, no significant interaction was observed between GS and HA for the studied microelements. 
Table 3. Growth and feed value of blue panic at two different growth stages, and at various levels of HA applications.

\begin{tabular}{|c|c|c|c|c|c|c|c|c|c|}
\hline \multicolumn{2}{|c|}{ Treatments } & \multirow{3}{*}{ PH (cm) } & \multicolumn{7}{|c|}{ Parameters } \\
\hline \multirow{2}{*}{$\begin{array}{c}\text { Growth } \\
\text { Stage (GS) }\end{array}$} & \multirow{2}{*}{$\begin{array}{c}\text { HA Level } \\
\left(\mathrm{Kg} \mathrm{ha}^{-1}\right)\end{array}$} & & \multirow{2}{*}{$\begin{array}{c}\text { DM } \\
\left(\begin{array}{c}\text { tons ha- } \\
1\end{array}\right)\end{array}$} & \multicolumn{2}{|c|}{$\underline{\text { DM partitioning (\%) }}$} & \multirow{2}{*}{$\begin{array}{c}\text { CP } \\
(\% \mathrm{DM})\end{array}$} & \multirow{2}{*}{$\begin{array}{l}\text { NDF } \\
(\% \text { of } \\
\text { DM })\end{array}$} & \multirow{2}{*}{$\begin{array}{c}\text { ADF } \\
(\% \text { of DM })\end{array}$} & \multirow{2}{*}{$\begin{array}{l}\text { DDM } \\
(\% \text { of } \\
\text { DM) }\end{array}$} \\
\hline & & & & $\underline{\text { Stem }}$ & $\underline{\text { Leaf }}$ & & & & \\
\hline \multicolumn{10}{|c|}{ Before flowering (BF) stage } \\
\hline & 0 & 42.11 & 6.16 & 34.60 & 65.40 & 8.60 & 58.81 & 31.23 & 64.54 \\
\hline & 15 & 42.20 & 6.16 & 35.44 & 64.56 & 8.75 & 58.32 & 30.97 & 64.74 \\
\hline & 30 & 44.18 & 6.50 & 35.84 & 64.16 & 9.20 & 57.35 & 30.45 & 65.15 \\
\hline & 45 & 45.90 & 6.73 & 36.00 & 64.00 & 9.56 & 56.14 & 29.81 & 65.65 \\
\hline & 60 & 46.00 & 6.80 & 36.00 & 64.00 & 9.37 & 55.51 & 27.48 & 67.47 \\
\hline & 75 & 46.50 & 6.82 & 35.20 & 64.80 & 9.60 & 55.16 & 26.10 & 68.54 \\
\hline & 90 & 48.18 & 6.98 & 34.34 & 65.66 & 9.61 & 54.00 & 24.20 & 70.02 \\
\hline \multicolumn{10}{|c|}{ After flowering (AF) stage } \\
\hline & 0 & 48.40 & 6.55 & 44.12 & 55.88 & 7.00 & 72.24 & 38.36 & 58.98 \\
\hline & 15 & 50.40 & 6.81 & 44.80 & 55.20 & 7.00 & 72.01 & 38.24 & 59.07 \\
\hline & 30 & 52.12 & 7.19 & 46.12 & 53.88 & 7.32 & 70.81 & 37.60 & 59.57 \\
\hline & 45 & 55.18 & 7.40 & 48.96 & 51.04 & 7.65 & 69.40 & 36.85 & 60.16 \\
\hline & 60 & 55.00 & 7.32 & 49.00 & 51.00 & 7.50 & 69.31 & 34.80 & 61.76 \\
\hline & 75 & 55.80 & 7.56 & 49.60 & 50.40 & 7.75 & 69.22 & 32.76 & 63.35 \\
\hline & 90 & 55.80 & 7.80 & 50.12 & 49.88 & 7.84 & 66.80 & 30.00 & 65.50 \\
\hline LSD GS & & 2.55 & 0.32 & 2.04 & 2.15 & 0.53 & 4.01 & 2.13 & 4.11 \\
\hline LSD HA & & 3.01 & 1.20 & 2.86 & 3.53 & 0.36 & 4.00 & 3.10 & 2.54 \\
\hline \multicolumn{10}{|c|}{ Statistical significance: } \\
\hline GS & & $*$ & * & * & $*$ & * & * & * & * \\
\hline HA & & * & $*$ & * & * & $*$ & $*$ & $*$ & $*$ \\
\hline $\mathrm{CS} \times \mathrm{HA}$ & & NS & NS & NS & NS & NS & NS & NS & NS \\
\hline
\end{tabular}

$\mathrm{PH}=$ Plant height DM = Average Dry matter per cut; $\mathrm{CP}=$ Crude protein, $\mathrm{NDF}$, Neutral detergent fiber; $\mathrm{ADF}=$ acid; detergent fiber; $\mathrm{DDM}=$ digestible dry matter

Table 4. Macro-elemental contents of blue panic at two different growth stages, and at various levels of HA applications.

\begin{tabular}{|c|c|c|c|c|c|c|c|c|}
\hline \multicolumn{2}{|c|}{ Treatments } & & & \multicolumn{5}{|c|}{ Macro-minerals $\left(\mathrm{g} \mathrm{kg}^{-1} \mathrm{DM}\right)$} \\
\hline $\begin{array}{c}\text { Growth } \\
\text { Stage (GS) }\end{array}$ & $\begin{array}{l}\text { HA Level } \\
\left(\mathrm{Kg} \mathrm{ha}^{-1}\right)\end{array}$ & $\mathbf{N}$ & $\mathbf{P}$ & $\mathbf{K}$ & $\mathbf{C a}$ & Mg & $\mathbf{S}$ & $\mathbf{N a}$ \\
\hline \multicolumn{9}{|c|}{ Before flowering (BF) stage } \\
\hline & 0 & 14.33 & 2.30 & 21.90 & 3.90 & 2.31 & 2.22 & 2.20 \\
\hline & 15 & 14.58 & 2.40 & 22.00 & 4.10 & 2.52 & 2.40 & 2.13 \\
\hline & 30 & 15.34 & 2.40 & 22.42 & 4.50 & 2.40 & 2.30 & 2.10 \\
\hline & 45 & 15.54 & 2.40 & 22.60 & 4.41 & 2.40 & 2.32 & 2.08 \\
\hline & 60 & 15.63 & 2.60 & 22.80 & 4.90 & 2.48 & 2.36 & 2.04 \\
\hline & 75 & 16.01 & 2.84 & 22.92 & 4.88 & 2.50 & 2.42 & 2.01 \\
\hline & 90 & 16.02 & 2.90 & 23.11 & 4.91 & 2.53 & 2.43 & 2.00 \\
\hline \multicolumn{9}{|c|}{ After flowering (AF) stage } \\
\hline & 0 & 13.42 & 2.10 & 19.10 & 3.42 & 2.25 & 2.16 & 2.12 \\
\hline & 15 & 13.87 & 2.16 & 20.21 & 4.12 & 2.30 & 2.20 & 2.12 \\
\hline & 30 & 14.40 & 2.20 & 20.60 & 4.53 & 2.30 & 2.20 & 2.05 \\
\hline & 45 & 14.95 & 2.23 & 20.60 & 4.60 & 2.33 & 2.20 & 2.00 \\
\hline & 60 & 14.70 & 2.21 & 20.60 & 4.70 & 2.30 & 2.22 & 2.21 \\
\hline & 75 & 15.12 & 2.30 & 20.70 & 4.82 & 2.30 & 2.28 & 2.15 \\
\hline & 90 & 15.27 & 2.32 & 22.80 & 4.92 & 2.50 & 2.40 & 2.03 \\
\hline LSD CS & & 1.14 & 0.18 & 2.56 & 0.98 & 0.12 & 0.20 & 0.16 \\
\hline LSD HA & & 0.52 & 0.20 & 1.20 & 1.10 & 0.16 & 0.19 & 0.15 \\
\hline \multicolumn{9}{|c|}{ Statistical significance: } \\
\hline $\mathrm{CS}$ & & $*$ & $*$ & $*$ & $\mathrm{NS}$ & $*$ & NS & NS \\
\hline $\mathrm{HA}$ & & $*$ & $*$ & $*$ & $\mathrm{NS}$ & $*$ & $\mathrm{NS}$ & NS \\
\hline $\mathrm{CS} \times \mathrm{HA}$ & & NS & NS & NS & $\mathrm{NS}$ & NS & $\mathrm{NS}$ & $\mathrm{NS}$ \\
\hline
\end{tabular}


Table 5. Micro-elemental contents of blue panic at two different growth stages, and at various levels of HA applications.

\begin{tabular}{|c|c|c|c|c|c|c|c|}
\hline \multicolumn{2}{|c|}{ Treatments } & \multicolumn{6}{|c|}{ Micro-minerals (mg kg-1 DM) } \\
\hline $\begin{array}{c}\text { Growth } \\
\text { Stage (GS) }\end{array}$ & $\begin{array}{c}\text { HA Level } \\
\left(\mathrm{Kg} \mathrm{ha}^{-1}\right)\end{array}$ & B & Mn & $\mathbf{F e}$ & Co & $\mathbf{C u}$ & $\mathbf{Z n}$ \\
\hline \multicolumn{8}{|c|}{ Before flowering (BF) stage } \\
\hline & 0 & 4.51 & 62.55 & 80.44 & 0.02 & 6.72 & 22.96 \\
\hline & 15 & 4.60 & 62.60 & 85.05 & 0.10 & 8.90 & 23.98 \\
\hline & 30 & 4.60 & 62.60 & 90.84 & 0.10 & 8.80 & 25.90 \\
\hline & 45 & 4.60 & 62.63 & 93.44 & 0.12 & 8.82 & 25.93 \\
\hline & 60 & 4.68 & 62.60 & 93.13 & 0.12 & 8.86 & 25.91 \\
\hline & 75 & 4.70 & 62.60 & 93.51 & 0.22 & 8.92 & 26.00 \\
\hline & 90 & 4.73 & 62.80 & 93.52 & 0.23 & 8.92 & 26.02 \\
\hline \multicolumn{8}{|c|}{ After flowering (AF) stage } \\
\hline & 0 & 4.35 & 79.81 & 70.12 & 0.10 & 5.66 & 16.00 \\
\hline & 15 & 4.40 & 80.02 & 74.17 & 0.10 & 6.70 & 18.12 \\
\hline & 30 & 4.40 & 79.90 & 74.70 & 0.10 & 6.70 & 19.30 \\
\hline & 45 & 4.43 & 79.90 & 75.25 & 0.12 & 6.70 & 19.30 \\
\hline & 60 & 4.40 & 79.98 & 75.00 & 0.18 & 6.72 & 19.50 \\
\hline & 75 & 4.40 & 80.00 & 75.42 & 0.20 & 6.78 & 19.34 \\
\hline & 90 & 4.60 & 80.03 & 75.57 & 0.18 & 6.90 & 19.40 \\
\hline LSD GS & & 0.20 & 8.32 & 9.10 & - & 1.16 & 4.10 \\
\hline LSD HA & & 0.21 & - & 5.00 & - & 1.04 & 3.11 \\
\hline \multicolumn{8}{|c|}{ Statistical significance: } \\
\hline CS & & $*$ & * & $*$ & NS & * & $*$ \\
\hline HA & & $*$ & NS & $*$ & NS & $*$ & $*$ \\
\hline CS x HA & & NS & NS & NS & NS & NS & NS \\
\hline
\end{tabular}

\section{DISCUSSION}

Results of the growth parameters, including plant height and DM, indicated that biomass was higher for cutting the plants at AF stage, compared with BF. However, subsequent nutrient analyses indicate that the feed value actually decreased at the later stage cutting, compared to first stage. This could be explained by decreasing leaf/stem ratios, as well as increases in cell wall materials, ADF, and NDF (Gidenne, 2015). Humic acid enhances crop growth parameters due to its positive effect on soil physical and chemical properties, and nutrient uptake, and it additionally decreases plant oxidative stress (Goto and Gordon, 1991; Daur, 2013, 2014). Based on the chemical analyses of the feed values, the blue panic had suitable crude protein content at BF stage, whereas at the AF stage, this value dropped below the optimal level for rumen functioning, which is $7.5 \%$ (van Soest, 1982). This change was attributed to increase in cellulose content, where protein content declines rapidly. This result suggests cutting of the crop at BF stage. In addition, compromising quantity with quality by utilizing the AF stage, then it will require supplementary proteins, for example from oilseed cakes, or non-protein nitrogen (NPN) sources such as urea, or biuret. It is also possible to achieve the required protein content by mixing the grass with high protein forage crops, such as alfalfa, berseem, or sesbania species. The observed lower ADF and NDF contents, combined with high DDM or DM values in the tender stages of a crop, are comparable to observations from previous studies (Theodoridou et al. 2011; Peiretti et al. 2013). This can be explained by the decline in plant tenderness due to development of xylem tissues for water transport, and the accumulation of cellulose and other complex carbohydrates in later stage of the plants. An optimum range of 17-21\% ADF and 25$33 \%$ NDF for cows during their milk production peak has been suggested in the past (Kawas et al. 1991, Zebeli et al. 2008). However, our data for blue panic ADF and NDF contents were similar to many warm season grasses, including Bothriochloa ischaemum, Cynodon dactylon, Eragrostis curvula (Restelatto et al. 2014; Soto-Navarro et al. 2014). Recent studies indicate that exact quantifications of dietary ADF and NDF are difficult, because it involves feed intake behavior, ruminal mat formation, rumination and salivation, ruminal motility, and animal type etc (Zebeli et al. 2012, Soto-Navarro et al. 2014). Generally, forages with lower ADF and NDF contents are less filling, since they are highly digestible, and therefore allow a larger dry matter intake, which makes them desirable fodder for lactating animals. Nevertheless, the desirability of feed depends on its availability and purpose. For animals in late-lactation, dry cows, or heifers, blue panic from both growth stages can be very suitable, as the comparatively high ADF and NDF will sustain these animals. Furthermore, our results regarding the effect of HA on forage quality are supported by Nazli et al. (2014), who reported that leonardite (a raw source of HA) has positive effects on feed CP and ADF levels when mixing it with inorganic fertilizers.

The high mineral contents in early growth stages are common in almost all crops, because mineral absorption and dry matter production do not occur at the same rate. In 
young blue panic grass, element absorption was relatively rapid, whereas dry matter production rather slow. Both results are in general agreement with earlier findings (Lee and Smith, 1972; Kilcher and Heinrichs, 1974; Rominger et al. 1975; Daur et al. 2011; Barker and Pilbeam, 2015). The increase in macro- and microelemental composition with increasing HA levels is attributed to the improvement of the soil's physical and chemical properties. Moreover, the unique structural characteristics of humic acids with large number of oxygen containing functional groups $\left(\mathrm{CO}_{2} \mathrm{H}_{2}, \mathrm{OH}\right.$, phenols, and $\left.\mathrm{C}=\mathrm{O}\right)$, play a key role to enhance nutrient availability by the chelation of metallic nutrient elements (Nardi, et al., 2009). Better root architecture and increased root area by stimulating root elongation and lateral root development have been reported as important phenomena responsible for improved nutrient uptake by humic acids (Canellas et al., 2002, 2011; Jindo et al., 2012).

All these ultimately lead to enhanced plant nutrient uptake, as reported by earlier studies (Yona and Aviad, 1990; Eyheraguibel et al. 2008; Daur, 2013).

The lack of significant effects of HA level on $\mathrm{Ca}, \mathrm{S}$, $\mathrm{Na}$, and $\mathrm{Co}$ is most likely due to the already high levels of these elements in the soil. We discussed above how the blue panic $\mathrm{N}$ content relates to feed value through its $\mathrm{CP}$ values. In addition, the foliar $\mathrm{P}$ content was higher than 2 $\mathrm{g} \mathrm{kg}^{-1}$, and $\mathrm{K}$ content was higher than $8 \mathrm{~g} \mathrm{~kg}^{-1}$ for all treatments, which are both recommended levels for animal feed (Underwood, 1981; Main et al. 2013). Similarly, the blue panic $\mathrm{Ca}, \mathrm{Mg}, \mathrm{S}$, and $\mathrm{Na}$ concentrations $(6,2,1$, and $1 \mathrm{~g} \mathrm{~kg}^{-1}$, respectively) are considered adequate for animal feed as well (Sykes and Field, 1972; NRC, 1978, 1984, 1985: ARC, 1980, McDowell, 1985; Little, 1985; Minson, 2012, Knowles and Grace, 2014). The optimal dose of boron (B) for animals is not generally available from literature, although it was recently established as an essential element for animals (Kabu et al. 2015; Kabu and Uyarlar, 2015). In addition, the blue panic grass was found to be satisfactory for $\mathrm{Mn}$ and $\mathrm{Fe}$, since $40 \mathrm{mg} \mathrm{kg}^{-1}$ for $\mathrm{Mn}$, and $50 \mathrm{mg} \mathrm{kg}^{-1}$ for $\mathrm{Fe}$, are considered adequate for farm animals (McDowell, 1985). Cobalt (Co) was found to be adequate in blue panic grass as $0.1-02 \mathrm{mg} \mathrm{kg}^{-1}$ of dry matter is required (NRC. 1985). However, it is rare for grasses to have enough Co to meet the demands of farm animals, because most foliage from pastures have 0.10 ppm or less Co (Hodgson et al. 1962). Finally, pastures with 8-14 mg kg-1 $\mathrm{Cu}$, and $12-35 \mathrm{mg} \mathrm{kg}^{-1} \mathrm{Zn}$, are considered adequate for animals (McDowell et al. 1978; ARC, 1980).

\section{CONCLUSIONS}

This article underscores the potential for growing blue panic grass in saline conditions. Until today, this crop has not received much consideration because of the lack of scientific information about its feed value. In this article, we explore the feed value of blue panic grass more comprehensively, in order to fill this gap in the current literature.
The study suggests the application of $75-90 \mathrm{~kg} \mathrm{ha}^{-1}$ HA to the soil, before sowing - to enhance both the yield and quality of the crop, whereas cutting of the crop at BF (before flowering) for quality feed, and AF (after flowering) stage for animals in late-lactation, dry cows, or heifers/ or with feed supplement for milking animals may recommended.

\section{ACKNOWLEDGEMENTS}

This work was funded by the Deanship of Scientific Research (DSR), King Abdulaziz University, Jeddah, under grant No. (155-458-D1435). The authors, therefore, acknowledge with thanks DSR technical and financial support.

\section{LITERATURE CITED}

AOAC. 2000. Official Methods of Analysis of the Association of Official Analytical Chemist. 17th ed. AOAC, Washington, DC. USA.

ARC. 1980. The nutrient requirements of ruminant livestock. Commonwealth Agricultural Bureaux, Farnham Royal, U.K.

Atis, I., Konuskan, O., Duru, M., Gozubenli H., and Yilmaz, S. 2012. Effect of harvesting time on yield, composition and forage quality of some forage sorghum cultivars. Int. J. Agric. Biol. 14: 879-886.

Barker, A.V., Pilbeam, D.J. 2015. Handbook of plant nutrition, second edition. CRC press, Taylor \& Francis Group, LLC. $747 \mathrm{p}$.

Barry, T.N. 2013. The feeding value of forage brassica plants for grazing ruminant livestock. Anim. Feed Sci. Tech. 181: 1525

Daur, I. 2013. Comparative study of farm yard manure and humic acid in integration with inorganic-n on wheat (Triticum aestivum L.) Growth and yield. Tarim Bilim Derg. 19: 170-177.

Daur, I. 2014. Effect of humic acid on growth, protein and mineral composition of pearl millet [Pennisetum glaucum (L.) R.Br.] Fodder. Pak. J. Bot. 46(2): 505-509.

Daur, I., and Tatar, Ö. 2013. Effects of gypsum and brassinolide on soil properties, and berseem (Trifolium alexandrinum L.) growth, yield and chemical composition grown on saline soil. Legume Res., 36 (4): 306 - 311.

Daur, I., Sepetoglu, H., and Sindel, B. 2011. Dynamics of faba bean growth and nutrient uptake and their correlation with grain yield. J. plant Nutr. 34: 1360-1371.

Dong, C.F.,, Shen, X.Y., Ding, C.L., Xu, N.X., Cheng, Y.H., and $\mathrm{Gu}$, H.R. 2013. The feeding quality of rice (Oryza sativa L.) straw at different cutting heights and the related stem morphological traits. Field Crop Res. 141: 1-8.

Eyheraguibel, B., Silvestre, J., and Morard, P. 2008. Effects of humic substances derived from organic waste enhancement on the growth and mineral nutrition of maize. Bioresour. Technol. 99(10): 4206-4212.

Gidenne, T. 2015. Dietary fibres in the nutrition of the growing rabbit and recommendations to preserve digestive health: a review. Animal. 9(2): 227-242.

Goto , M., and Gordon, A.H. 2006. Changes in cell-wall composition and degradability of sorghum during growth and maturation. DOI: $10.1002 /$ jsfa.2740540107.

Geren, Hakan. 2014. Dry matter yield and silage quality of some winter cereals harvested at different stages under mediterranean climate conditions. Turk J Field Crops. 19(2): 206-211.

Geren, Hakan. and Kavut, T.Y. 2015. Effect of different plant densities on the yield and some silage quality characteristics 
of giant king grass (Pennisetum hybridum) under mediterranean climatic conditions. Turk J Field Crops. 20(1), 85-91.

Hameed, M., Batool, S., Naz, N., Nawaz, T., and Ashraf, M. 2012. Leaf structural modifications for drought tolerance in some differentially adapted ecotypes of blue panic (Panicum antidotale Retz.). Acta Physiol. Plant. 34(4): 1479-1491.

Hodgson, J.F., Leach, R.M., and Allway, W.H. 1962. Micronutrients in soils and plants in relation to animal nutrition. J. Agri. Food Chem. 10: 171-174.

Kabu, M., and Uyarlar, C. 2015. The effects of borax on milk yield and selected metabolic parameters in Austrian Simmental (Fleckvieh) cows. Vet Med - Czech. 60(4): 175180.

Kabu, M., Uyarlar, C., Katarzyna, Z., Wanda, M., and Przemysław, S. 2015. The role of boron in animal health. J. Elem. 20(2): 535-541.

Kawas, J.R, Jorgensen, N.A., and Danelon, J.L. 1991. Fiber requirements of dairy cows: optimum fiber level in lucernebased diets for high producing cows. Livest. Prod. Sci. 28(2): 107-119.

Kilcher, M.R., Heinrichs, D.H. 1974. Contribution of stems and leaves to the yield and nutrient level of irrigated alfalfa at different stages of development. Can. J. Soil Sci. 54: 739742 .

Knowles, S.O., and Grace, N.D. 2014. A recent assessment of the elemental composition of New Zealand pastures in relation to meeting the dietary requirements of grazing livestock. J. Anim. Sci. 92(1): 303-310.

Lee, C., Smith, D. 1972. Changes in the concentration of nitrogenous fractions in alfalfa herbage with advances in maturity. Agron. J. 64: 326-327.

Little, D.A. 1985. The dietary mineral requirements of ruminants; implications for the utilization of tropical fibrous agricultural residues. Pages 34-43 In: P.T. Doyle, ed. The utilization of fibrous agricultural residues as animal feeds. IDP, Canberra, Australia.

Long, R.J., Apori, S.O., Castrocorrespondence, F.B ., Grskov, E.R. 1999. Feed value of native forages of the Tibetan Plateau of China. Anim. Feed Sci. Tech. 80(2): 101-113.

Main, M.H., Lynch, D.H., Voroney, R.P., and Juurlink, S. 2013. Soil Phosphorus Effects on Forage Harvested and Nitrogen Fixation on Canadian Organic Dairy Farms. Agron. J. 105(3): 827-835.

McDowell, L.R. 1985. Nutrition of grazing ruminants in warm climates. Academic Press, New York.

McDowell, L.R., Houser, R.H. and Fick, K.R. 1978. Iron, zinc and manganese in ruminant nutrition. Pages 108-116. In: J.R. Conrad and L.R. McDowell, eds. Latin American symposium on mineral nutrition research with grazing ruminants. University of Florida, Gainesville, Florida.

McDowell, L.R., Houser, R.H., and Fick, K.R. 1978. Iron, zinc and manganese in ruminant nutrition. Pages 108-116. In: J.R. Conrad and L.R. McDowell, eds. Latin American symposium on mineral nutrition research with grazing ruminants. University of Florida, Gainesville, Florida.

Mertens, D.R. 1987. Predicting intake and digestibility using mathematical models of ruminal function. J. Anim. Sci. 64:1548-1558.

Minson, D. J. 2012. Magnesium in ruminant nutrition, In: Forage in ruminant nutrition, Academic Press Inc. San Diego, California 92101, United States, 463 Pp.

Moore, J.E., Burns, J.C., Fisher, D.S., 1996. Multiple regression equations for predicting relative feed value of grass hays. In: Proceedings of the 1996 American Forage and Grassland Council, Vancouver, BC, pp. 35-139.
Nawaz, T., Hameed, M., Ashraf, M., Batool, S., and Naz, N. 2013. Modifications in root and stem anatomy for water conservation in some diverse blue panic (Panicum antidotale retz.) ecotypes under drought stress. Arid Land Res. Manag. 27(3): 286-297.

Nazli, R.I., Kuşvuran, A., İnal, İ., Demirbaş, A., Tansi, V. 2014. Effects of different organic materials on forage yield and quality of silage maize (Zea mays L.). Turk J Agric For. 38: 23-31.

Nelson, D.W. ,and Sommers, L.E. 1996. Total carbon, organic carbon, and organic matter. In: Methods of Soil Analysis, Part 2, 2nd ed., A.L. Page et al., eds. Agronomy. 9:961-1010. Am. Soc. of Agron., Inc. Madison, WI.

NRC. 1978. Nutrient requirements of domestic animals. Nutrient requirements of dairy cattle. 5th edition. National Academy of Sciences, Washington, D.C.

NRC. 1984. Nutrient requirements of domestic animals. Nutrient requirements of sheep. 6th edition. National Academy of Sciences, Washington, D.C.

NRC. 1985. Nutrient requirements of sheep. 6th edition. National Research Council, National Academy Press, Washington, D.C.

Page A.L., Miller, R.H., and Keeney, D.R. 1982. Methods of soil analysis, Part 2. Chemical and microbiological properties (Agronomy), 2nd ed. Soil Sci. Soc. Am., Madison, Wisconsin, USA.

Peiretti, P.G., Gai, F., and Tassone, S. 2013. Fatty acid profile and nutritive value of quinoa (Chenopodium quinoa Willd.) seeds and plants at different growth stages. Anim Feed Sci. Tech. 183: 56-61.

Restelatto, R., Pavinato, P.S., Sartor, L.R., Paixao, and S.J. 2014. Production and nutritional value of sorghum and black oat forages under nitrogen fertilization. Grass Forage Sci. 69(4): 693-704.

Rominger, R.S., Smith, D., Peterson, L.A. 1975. Changes in elemental concentrations in alfalfa herbage at two soil fertility levels with advance in maturity. Commun. Soil Sci. Plant Anal. 6: 163-180.

Ryan, J., Estefan, G., and Rashid, A. 2001. Soil and plant analysis laboratory manual, 2nd ed. Aleppo, Syria: International Center for Agricultural Research in the Dry Areas and the National Agricultural Research Center.

Shahbaz, M., Iqbal, M., and Ashraf, M. 2011. Response of differently adapted populations of blue panic grass (Panicum antidotale Retz.). J. Appl. Bot. Food Qual. 84: 134 - 141.

Soto-Navarro, S.A. , Lopez, R., Sankey, C., Capitan, B.M., Holland, B.P., Balstad L.A., and Krehbiel, C.R. 2014. Comparative digestibility by cattle versus sheep: Effect of forage quality. J. Anim. Sci. 92(4): 1621-1629.

Sykes, A.R. and Field, A.C. 1972. Effects of dietary deficiencies of energy, protein and calcium on the pregnant ewe. I. Body composition and mineral content of the ewes. J. Agr. Sci. 78:109-117.

Theodoridou, K., Aufrère, J., Andueza, D., Le Morvan, A., Picard, F., Stringano, E., Pourrat, J., Mueller-Harvey, I., and Baumont, R. 2011. Effect of plant development during first and second growth cycle on chemical composition, condensed tannins and nutritive value of three sainfoin (Onobrychis viciifolia) varieties and Lucerne. Grass Forage Sci. 66(3): 402-414.

Underwood, E.J. 1981. The mineral nutrition of livestock. 2nd edition. Commonwealth Agricultural Bureau, London.

Van Soest, P.J. 1982. Nutritional ecology of the ruminant. O and B Books, Oregon.

Van Soest, P.J., Robertson, J.B., Lewis, B.A. 1991. Methods for dietary fiber, neutral detergent fiber, and nonstarch 
polysaccharides in relation to animal nutrition. J. Dairy Res. 74(10): 3583-3597.

Wasim, M. A., Iqbal, R.M., and Akram, M. 2013. Growth and physiology of panicum species for thermotolerance under hydroponic conditions. J. Anim. Plant Sci. 23(3): 860-864.

Yona, C., and Aviad, T. 1990. Effects of humic substances on plant growth. In: humic substances in soil and crop sciences: selected readings. P. MacCarthy, C.E. Clapp, R.L. Malcolm and P.R. Bloom, eds. p. 161-186. doi:10.2136/1990.humicsubstances.c7.
Zebeli, Q., Aschenbach, J.R., Tafaj, M., Boguhn, J., Ametaj, B.N., Drochner, W. 2012. Invited review: Role of physically effective fiber and estimation of dietary fiber adequacy in high-producing dairy cattle. J. Dairy Sci. 95(3): 1041-1056.

Zebeli, Q., Dijkstra, J., Tafaj, M., Steingass, H., Ametaj, B.N., and Drochner, W. 2008. Modeling the adequacy of dietary fiber in dairy cows based on the responses of ruminal $\mathrm{pH}$ and milk fat production to composition of the diet. J. Dairy Sci. 91(5): 2046-2066. 